\title{
Minimal transmission of SARS-CoV-2 from paediatric COVID-19 cases in primary schools, Norway, August to November 2020
}

Lin T Brandal ${ }^{1,2}$, Trine S Ofitserova ${ }^{1}$, Hinta Meijerink ${ }^{1}$, Rikard Rykkvin ${ }^{1}$, Hilde M Lund $^{1}$, Olav Hungnes ${ }^{1}$, Margrethe Greve-

Isdah L $^{1}$, Karoline Bragstad ${ }^{1}$, Karin Nygård ${ }^{1}$, Brita A Winje ${ }^{1}$

1. Norwegian Institute of Public Health, Oslo, Norway

2. European Programme for Public Health Microbiology Training (EUPHEM), European Centre for Disease Prevention and Control, (ECDC), Stockholm, Sweden

Correspondence: Lin T Brandal (lin.thorstensen.brandal@fhi.no)

Brandal Lin T, Ofitserova Trine S, Meijerink Hinta, Rykkvin Rikard, Lund Hilde M, Hungnes Olav, Greve-Isdahl Margrethe, Bragstad Karoline, Nygård Karin, Winje Brita A. Minimal transmission of SARS-CoV-2 from paediatric COVID-19 cases in primary schools, Norway, August to November 2020 . Euro Surveill. 2021;26(1): pii=2002011. https://doi.org/10.2807/1560-7917.ES.2020.26.1.2002011

An intense debate on school closures to control the COVID-19 pandemic is ongoing in Europe. We prospectively examined transmission of SARS-CoV-2 from confirmed paediatric cases in Norwegian primary schools between August and November 2020. All in-school contacts were systematically tested twice during their quarantine period. With preventive measures implemented in schools, we found minimal child-to-child $(0.9 \%, 2 / 234)$ and child-to-adult $(1.7 \%, 1 / 58)$ transmission, supporting that under 14 year olds are not the drivers of SARS-CoV-2 transmission.

Since summer 2020 , a considerable increase in coronavirus disease (COVID-19) infections has been reported across Europe [1], including in Norway [2]. A better understanding of children's role in transmission of severe acute respiratory syndrome coronavirus 2 (SARS-CoV-2) in school settings is urgently needed. Although several studies have reported limited transmission of SARS-CoV-2 among children in school settings [3-7], few have comprised systematic testing of contacts, including asymptomatic contacts. We aimed to examine transmission of SARS-CoV-2 from confirmed paediatric COVID-19 cases in primary schools in Norway by systematically testing all contacts within the school twice during their quarantine period.

\section{Identification of paediatric COVID-19 cases in primary schools and their contacts \\ Oslo and Viken were the counties in Norway with the highest 14-day incidence of COVID-19, ranging from 19.3 to 94.9 cases per 100,000 inhabitants in weeks 36 to 462020 [2]. During our observation period, from 28 August 2020 to 11 November 2020, the number of confirmed cases increased in these counties, including

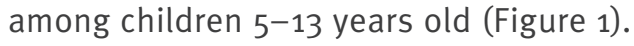

An index case was defined as a case aged $5-13$ years in Oslo or Viken county with PCR-confirmed SARS-CoV-2 infection, who had attended school within 48 hours before symptom onset or date of sampling. We prospectively included contact tracings around 13 index cases. For each index case, public health officials identified exposed child and adult school contacts (Figure 2). All consenting cases and contacts delivered two self-collected saliva samples; the first was collected as soon as possible after they were identified, and the second was collected at the end of their 10-day quarantine period (Figure 2). We excluded contact tracings with adult COVID-19 index cases.

A primary case was defined as a school contact who tested positive for SARS-CoV-2 in the first saliva sample. A secondary case was defined as a school contact who tested positive for SARS-CoV-2 in the second saliva sample, following a first negative test.

Study invitations were sent to adult contacts (staff) and parents of child contacts through the school's digital communication platform. We distributed equipment and detailed instructions for self-collection of two saliva samples to consenting participants on the same day. The first saliva sample was taken the following morning before eating, drinking or brushing teeth; the second saliva sample was taken at the end of the quarantine period with the same instructions (Figure 2). The participants added viral transport media to the saliva sample. Each saliva sample was analysed for SARS-CoV-2 using PCR (RdRp gene) [8] at the National Reference Laboratory of influenza and coronaviruses with outbreak potential (including SARSCoV-2) at the Department of Virology at the Norwegian Institute of Public Health in Oslo. 


\section{FIGURE 1}

Laboratory-confirmed COVID-19 cases by date of sampling and age, Oslo and Viken counties, Norway, 28 August-11 November $2020(n=9,416)$



Age groups

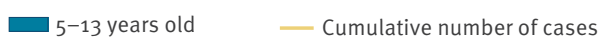
$\square$ All other ages

COVID-19: coronavirus disease.

Source: Norwegian Surveillance System for Communicable Diseases (MSIS).

\section{Minimal transmission of SARS-CoV-2 in primary schools}

Thirteen contact tracings from primary schools were included: eight in the age group 5-10 years old (grades 1-4) and five in the age group 11-13 years old (grades 5-7) (Figure 2). A total of 13 index cases and 292 school contacts participated in the study. In Contact Tracing 7, the index case did not consent to participate and saliva samples from this individual could not be collected. In Contact Tracing 8, two index cases were included, and in all the remaining 11 contact tracings one index case was included. Four of the 13 index cases had attended school with mild symptoms (in Contact Tracings 2, 3, 4 and 13); however, among these four index cases' contacts, only two primary cases (both in Contact Tracing 13) and no secondary case was identified. The remaining index cases were asymptomatic while attending school. All index cases, except one, had household members who were diagnosed with COVID-19 before the index cases themselves tested positive.

Among the 234 child contacts that were tested for SARS-CoV-2, two primary cases (0.9\%) and no secondary cases were identified, and among the 58 adult contacts one primary case $(1.7 \%)$ and no secondary cases were detected (Table 1). The three primary cases were identified in two different contact tracings (Contact Tracings 8 and 13, Figure 2).

The median number of contacts per index was 19 children (interquartile range (IQR): 16-21) and three adults (IQR: 2.5-6.5). We observed a high participation rate of $73 \%(234 / 319)$ (IQR: $63-89 \%)$ among child contacts and $78 \%(58 / 74)$ (IQR: $67-100 \%)$ among adult contacts (Figure 2, Table 1).
Self-collected saliva for detection of SARSCoV-2 in index cases and their school contacts

SARS-CoV-2 was confirmed in the self-collected saliva samples of 11 of the 13 index cases [8] (Table 2). In two index cases the saliva tests were negative. One child had drunk a glass of milk before the saliva collection. The other had a weakly positive nasopharyngeal sample (SARS-CoV-2 PCR cycle threshold (Ct) value of 35.73) 2 days before the saliva collection, which may explain the discrepant results. The median was 3 days (range: 2-6) between the confirmed nasopharyngeal SARS-CoV-2 sample and the first saliva sample, and 6 days (range: $3-10$ ) between the first and the second saliva samples.

All contacts, except three, tested negative in both saliva samples.

\section{Ethical statement}

The Regional Committees for Medical and Health Research Ethics in Norway approved this study (reference 151649). It complies with the European Union general data protection regulation (GDPR) requirements. Informed consent was obtained from adult contacts and parents of child contacts.

\section{Discussion}

This prospective study shows that transmission of SARS-CoV-2 from children under 14 years of age was minimal in primary schools in Oslo and Viken, the two Norwegian counties with the highest COVID-19 incidence and in which $35 \%$ of the Norwegian population resides. In a period of low to medium community transmission (a 14-day incidence of COVID-19 of $<150$ cases per 100,000 inhabitants) [9], when symptomatic children were asked to stay home from school, there were $<1 \%$ SARS-CoV-2-positive test results among child contacts and $<2 \%$ positive results in adult contacts in 13 contract tracings in Norwegian primary schools. In addition, self-collection of saliva for SARS-CoV-2 detection was efficient and sensitive ( $85 \%(11 / 13) ; 95 \%$ confidence interval: 55-98).

Studies from several European countries have shown minimal transmission of SARS-CoV-2 from paediatric index cases in schools [3-7]. However, the majority of these studies did not consider asymptomatic infections and did not screen all contacts. Our study confirms and strengthens these data, as we found minimal transmission even with a prospective design and systematic testing of all contacts twice during quarantine. Most of our index cases were asymptomatic and were tested for SARS-CoV-2 by PCR because they were contacts of positive household members, supporting that household transmission is a considerable source of SARS-CoV-2 infection in children $[6,10]$. Although the number of adult contacts was limited, we found SARSCoV-2 only in one $(1.7 \%)$ of the adult contacts. This supports findings in Sweden, the Netherlands and 


\section{FIGURE 2}

Overview of included COVID-19 contact tracings in schools, Oslo and Viken counties, Norway, 28 August-11 November $2020(\mathrm{n}=13)$

\begin{tabular}{|c|c|c|c|c|c|c|c|c|c|c|c|c|c|c|c|c|c|c|c|}
\hline \multirow{2}{*}{$\begin{array}{l}\text { Contact } \\
\text { tracing }\end{array}$} & \multicolumn{11}{|c|}{ Weeks (2020) } & \multirow{2}{*}{$\begin{array}{l}\text { Region } \\
\text { (county) }\end{array}$} & \multirow{2}{*}{$\begin{array}{l}\text { Age groups } \\
\text { (years) }\end{array}$} & \multicolumn{3}{|c|}{ Child contacts } & \multicolumn{3}{|c|}{ Adult contacts } \\
\hline & $\begin{array}{c}\text { Aug } \\
36\end{array}$ & $\begin{array}{l}\text { Sep } \\
37\end{array}$ & 38 & 39 & $\begin{array}{l}\text { Oct } \\
40^{\mathrm{a}}\end{array}$ & 41 & 42 & 43 & 44 & $\begin{array}{r}\text { Nov } \\
45\end{array}$ & 46 & & & $\begin{array}{c}\text { Total } \\
\mathrm{n}\end{array}$ & $\underset{n}{\text { Included }}$ & $\%$ & $\begin{array}{c}\text { Total } \\
\mathrm{n}\end{array}$ & $\underset{\mathrm{n}}{\text { Included }}$ & $\%$ \\
\hline \begin{tabular}{|l|}
1 \\
\end{tabular} & एा & IIIIII & & & & & & & & & & Viken & $5-10$ & 30 & 15 & 50 & 13 & 12 & 92 \\
\hline \begin{tabular}{|l|}
2 \\
\end{tabular} & & ШाI & Шl & & & & & & & & & Oslo & $11-13$ & 20 & 19 & 95 & 3 & 2 & 67 \\
\hline 3 & & & & IIIII & & & & & & & & Viken & $5-10$ & 45 & 34 & 76 & 9 & 4 & 44 \\
\hline 4 & & & & Шा & & & & & & & & Viken & $5-10$ & 18 & 16 & 89 & 3 & 2 & 67 \\
\hline 5 & & & & & & & IIIII & & & & & Viken & $5-10$ & 22 & 20 & 91 & 9 & 7 & 78 \\
\hline 6 & & & & & & & IIII & & & & & Viken & $5-10$ & 22 & 19 & 86 & 6 & 6 & 100 \\
\hline 7 & & & & & & & IIIII & & & & & Viken & $5-10$ & 19 & 4 & 21 & 4 & 4 & 100 \\
\hline 8 & & & & & & & एाI & & & & & Oslo & $5-10$ & 22 & 18 & 82 & 7 & 7 & 100 \\
\hline 9 & & & & & & & $\mathrm{DII}$ & & & & & Oslo & $11-13$ & 25 & 22 & 88 & 3 & 3 & 100 \\
\hline 10 & & & & & & & & $\pi$ & & & & Oslo & $11-13$ & 24 & 19 & 79 & 6 & 2 & 33 \\
\hline 11 & & & & & & & & & IIII & & & Oslo & $11-13$ & 25 & 9 & 36 & 3 & 3 & 100 \\
\hline 12 & & & & & & & & & & |ाW & & Oslo & $5-10$ & 26 & 22 & 85 & 4 & 3 & 75 \\
\hline 13 & & & & & & & & & & |l||| & IIII & Oslo & $11-13$ & 21 & 17 & 81 & 4 & 3 & 75 \\
\hline
\end{tabular}

$\square$ Quarantine $\square$ Study start $\square$ Saliva test 1 and $2 \quad \square$ No quarantine

COVID-19: coronavirus disease.

a Schools were closed due to autumn break in week 40 (28 September-2 October 2020).

b The first saliva samples were taken from the index case twice, with 3 days between the two; the second of these was positive. There were 6 days between the original nasopharyngeal sample and the first positive saliva sample. The third and last saliva sample was taken at the end of the case's 10-day quarantine.

${ }^{c}$ One or two primary cases (school contacts who tested positive for SARS-CoV-2 in the first saliva sample) were detected in the contact tracing.

\section{TABLE 1}

Outcome of contact tracings in schools from confirmed paediatric COVID-19 cases, Oslo and Viken counties, Norway, 28 August-11 November 2020

\begin{tabular}{|c|c|c|c|c|c|c|c|c|c|c|}
\hline \multirow{2}{*}{$\begin{array}{l}\text { Age group } \\
\text { (years) }\end{array}$} & \multirow{2}{*}{ Contact tracings } & \multirow{2}{*}{$\begin{array}{l}\text { Index } \\
\text { cases }\end{array}$} & \multirow{2}{*}{$\begin{array}{l}\text { Index likely } \\
\text { infected in } \\
\text { household }\end{array}$} & \multirow{2}{*}{$\begin{array}{l}\text { Asymptomatic } \\
\text { index cases }\end{array}$} & \multicolumn{2}{|c|}{ Included contacts } & \multicolumn{2}{|c|}{ Primary cases $^{a}$} & \multicolumn{2}{|c|}{ Secondary cases ${ }^{\mathrm{b}}$} \\
\hline & & & & & Children & Adults & Children & Adults & Children & Adults \\
\hline $5-10$ & 8 & $8^{c}$ & $7^{\mathrm{d}}$ & 6 & 148 & 45 & 1 & 0 & 0 & 0 \\
\hline $11-13$ & 5 & 5 & 5 & 3 & 86 & 13 & 1 & 1 & 0 & 0 \\
\hline Total & 13 & 13 & 12 & $9^{e}$ & 234 & 58 & 2 & 1 & 0 & 0 \\
\hline
\end{tabular}

COVID-19: coronavirus disease.

a Primary cases were defined as school contacts identified as SARS-CoV-2 positive in the first saliva sample.

b Secondary cases were defined as school contacts identified as SARS-CoV-2 positive in the second saliva sample, following a negative first test.

c In one contact tracing (no. 8), two index cases were present at the start of the study and both were included. They had overlapping schoolrelated contacts. In one contact tracing (no. 7), the index case did not consent to participate.

${ }^{d}$ One index case did not have a household member diagnosed with COVID-19 prior to their own diagnosis, but had visited a friend's household with adult COVID-19 cases before testing positive for SARS-CoV-2.

e Four index cases attended school while having mild symptoms (two in the age group 5-10 years and two in the age group 11-13 years). 
Detection of SARS-CoV-2 in saliva samples from paediatric COVID-19 index cases and their school contacts, Oslo and Viken counties, Norway, 28 August-11 November 2020

\begin{tabular}{|c|c|c|c|c|c|c|c|c|}
\hline \multirow[t]{2}{*}{$\begin{array}{l}\text { Contact } \\
\text { tracings }\end{array}$} & \multirow{2}{*}{$\begin{array}{c}\text { Age } \\
\text { (years) }\end{array}$} & \multirow[t]{2}{*}{ Index/contact } & \multirow{2}{*}{$\begin{array}{c}\text { Days between } \\
\text { nasopharyngeal } \\
\text { sample and saliva } 1^{\text {a }}\end{array}$} & \multicolumn{2}{|c|}{$\begin{array}{l}\text { Saliva } 1 \\
\text { (Ct value) }\end{array}$} & \multirow{2}{*}{$\begin{array}{c}\text { Days between } \\
\text { saliva } 1 \text { and } \\
\text { saliva } 2\end{array}$} & \multicolumn{2}{|c|}{$\begin{array}{l}\text { Saliva } 2 \\
\text { (Ct value) }\end{array}$} \\
\hline & & & & $\mathrm{nCoV}_{-} \mathrm{IP}_{2}$ & $\mathrm{nCoV} \mathrm{IP}_{4}$ & & $\mathrm{nCoV} \_\mathrm{P}_{2}$ & nCoV_IP4 \\
\hline 1 & 7 & Index & 3 & 24.56 & 23.24 & 10 & Neg & Neg \\
\hline 2 & 12 & Index & 5 & 26.71 & 24.96 & 6 & 34.92 & 33.8 \\
\hline 3 & 9 & Index & $\mathrm{NA}^{\mathrm{b}}$ & $\mathrm{NA}^{\mathrm{b}}$ & $\mathrm{NA}^{\mathrm{b}}$ & $8^{c}$ & 29.44 & 27.84 \\
\hline 4 & 7 & Index & 6 & $38.27^{d}$ & $32.97^{d}$ & 3 & Neg & Neg \\
\hline 5 & 7 & Index & 2 & 24.26 & 22.39 & 7 & 34.50 & 30.78 \\
\hline $6^{e}$ & 6 & Index & 5 & Neg & Neg & 7 & Neg & Neg \\
\hline $7^{f}$ & NA & Index & $N^{b}$ & $\mathrm{NA}^{\mathrm{b}}$ & $N^{b}$ & $\mathrm{NA}^{\mathrm{b}}$ & $N A^{b}$ & $N^{b}$ \\
\hline \multirow{3}{*}{$8^{g}$} & 8 & Index & 5 & 21.17 & 20.47 & 5 & 26.64 & 25.15 \\
\hline & 8 & Index & 3 & 24.86 & 23.93 & 5 & 27.49 & $25 \cdot 70$ \\
\hline & 8 & Contact (child) & $\mathrm{NA}^{\mathrm{b}}$ & 29.55 & 28.56 & 5 & 18.58 & $17 \cdot 40$ \\
\hline 9 & 12 & Index & 5 & 19.05 & 18.71 & 5 & 20.06 & 18.72 \\
\hline $10^{\mathrm{h}}$ & 11 & Index & 4 & Neg & Neg & 6 & Neg & Neg \\
\hline 11 & 11 & Index & 3 & 26.17 & 25.45 & 7 & 31.25 & 30.92 \\
\hline 12 & 6 & Index & 3 & $17 \cdot 47$ & 16.75 & 6 & 31.25 & 30.92 \\
\hline \multirow{3}{*}{13} & 11 & Index & 3 & 23.22 & 23.04 & 7 & 28.89 & $27 \cdot 39$ \\
\hline & 11 & Contact (child) & $\mathrm{NA}^{\mathrm{b}}$ & 39.17 & 35.42 & 7 & 23.49 & 22.01 \\
\hline & 26 & Contact (adult) & $\mathrm{NA}^{\mathrm{b}}$ & 11.08 & 10.66 & 7 & 29.32 & 28.15 \\
\hline
\end{tabular}

COVID-19: coronavirus disease; Ct: cycle threshold; NA: not applicable; Neg: negative.

a Nasopharyngeal sample is routinely used for detection of SARS-CoV-2 by PCR in medical microbiological laboratories in Norway.

${ }^{b}$ Not applicable, since no saliva sample was collected or no nasopharyngeal sample was taken before the saliva test.

' Number of days between nasopharyngeal sampling for routine detection of SARS-CoV-2 by PCR and sampling of saliva sample 2 . The first saliva sample was not collected from this index case.

d The first saliva sample was taken twice from this index case. The last saliva sample was taken at the end of their 10 -day quarantine.

e Index case drank milk before collection of saliva sample 1.

${ }^{f}$ In Contact Tracing 7, the index case did not consent to participate and thus no saliva samples were collected from this case.

g Two index cases were reported from the same class, with overlapping school-related contacts. Both were included in this contact tracing.

h The nasopharyngeal sample was positive for SARS-CoV-2 with a Ct value of 35.73, 4 days before sampling of saliva 1.

'Saliva 1' indicates the first saliva sample, taken as soon as the index case or case contact was identified, and 'saliva 2 ' indicates the second saliva sample, taken at the end of their 10-day quarantine.

Norway that teachers are not at higher risk of COVID-19 compared with other professions [11-13].

Few studies have used saliva samples for detection of SARS-CoV-2 in children and results have been discrepant [14-16]. Our data indicate that saliva samples have a good sensitivity; however, providing clear instructions for correct saliva sampling is necessary. Self-collection of saliva has advantages compared with nasopharyngeal sampling; it is non-invasive, comfortable, easy, cheap and can be done without involvement of healthcare workers. Of note, the number of observations here are small and our data do not enable us to calculate the specificity of self-collection of saliva. Although self-collection of saliva is an attractive method, further studies are needed to accurately define its sensitivity and specificity.

Norwegian schools were closed during the first SARSCoV-2 wave in spring 2020. After re-opening, all schools implemented infection prevention and control
(IPC) measures based on national guidelines. These included strengthened hygiene measures, physical distancing and a clear message to stay home if symptomatic, even with mild symptoms [17]. Use of face masks is not recommended in schools in Norway. We found that with the IPC measures implemented there is low to no transmission from SARS-CoV-2-infected children in schools. This finding strengthens national guidelines to adjust IPC measures according to the community transmission level [18], rather than closing primary schools for on-site teaching. Results from other studies further strengthen this position. Small school outbreaks elsewhere in Europe have been controlled by IPC measures $[5,6]$, whereas a lack of adequate IPC measures has resulted in a large COVID-19 school outbreak in Israel [19].

It is important to acknowledge that our results are valid for primary schools only, and not for secondary or high schools. SARS-CoV-2 transmission in those $\geq 14$ years old needs to be further studied. 


\section{Conclusions}

Systematic tracing and testing of school contacts of paediatric COVID-19 cases showed minimal childto-child and child-to-adult transmission in primary schools with implemented IPC measures. The results obtained during low to medium community transmission demonstrate the limited role of children in transmission of SARS-CoV-2 in school settings. This is an important finding in view of the ongoing discussions on school closures and use of quarantine for a large number of children. Strengthening of IPC measures in schools when community transmission levels increase could be an option.

\section{Acknowledgements}

We would like to thank the municipality doctors in Viken and the district doctors in Oslo for close and beneficial collaboration. Also, we are grateful for the participation of school administration of the involved schools. We thank the laboratory technicians and medical microbiologists (Dagny Haug Dorenberg and Kirsten Bjerkreim Strand) at the National Reference Laboratory of influenza and coronaviruses with outbreak potential (including SARS-CoV-2) at the Department of Virology at NIPH for managing the samples, performing the laboratory analyses and reporting the results. Finally, we acknowledge the other members of the Corona Child Study group at NIPH: Cathinka Halle Julin, Anja Kristoffersen, Heidi Lange, Lisbeth Næss, Ola Brynildsrud, Sylvi K Ladehaug and Thor Indseth for practical input and fruitful discussions. We thank coworkers at the Norwegian Surveillance System for Communicable Diseases for background data on COVID-19 prevalence.

\section{Conflict of interest}

None declared.

\section{Authors' contributions}

LTB, BAW, KN and HM designed the study. TSO, LTB, BAW implemented the study and collected data in collaboration with the municipalities. $\mathrm{OH}, \mathrm{KB}$ and $\mathrm{RR}$ were responsible for the laboratory analysis. LTB, BAW, TSO, HM, MGI, HML, RR and $\mathrm{OH}$ interpreted the data. LTB wrote the first draft of the manuscript. All authors revised the manuscript and approved the final version.

\section{References}

1. European Centre for Disease Prevention and Control (ECDC) Increased transmission of COVID-19 in the EU/EEA and the UK - thirteenth update. Stockholm: ECDC; 23 Oct 2020. Available from: https://www.ecdc.europa.eu/en/publications-data/ covid-19-risk-assessment-increased-transmission-thirteenthupdate

2. Norwegian Institute of Public Health (NIPH). Daily report and statistics about coronavirus and COVID-19. Oslo: NIPH. [Accessed 20 Nov 2020]. Available from: https://www.fhi. no/en/id/infectious-diseases/coronavirus/daily-reports/ daily-reports-COVID19/

3. European Centre for Disease Prevention and Control (ECDC). COVID-19 in children and the role of school settings in COVID-19 transmission. Stockholm: ECDC; 6 Aug 2020. Available from: https://www.ecdc.europa.eu/en/publications-data/ children-and-school-settings-covid-19-transmission

4. Heavey L, Casey G, Kelly C, Kelly D, McDarby G. No evidence of secondary transmission of COVID-19 from children attending school in Ireland, 2020. Euro Surveill. 2020;25(21):2000903.
https://doi.org/10.2807/1560-7917.ES.2020.25.21.2000903 PMID: 32489179

5. Otte Im Kampe E, Lehfeld AS, Buda S, Buchholz U, Haas W. Surveillance of COVID-19 school outbreaks, Germany, March to August 2020. Euro Surveill. 2020;25(38):2001645. https:// doi.org/10.2807/1560-7917.ES.2020.25.38.2001645 PMID: 32975186

6. Ehrhardt J, Ekinci A, Krehl H, Meincke M, Finci I, Klein J, et al. Transmission of SARS-CoV-2 in children aged o to 19 years in childcare facilities and schools after their reopening in May 2020, Baden-Württemberg, Germany. Euro Surveill. 2020;25(36):2001587. https://doi.org/10.2807/1560-7917. ES.2020.25.36.2001587 PMID: 32914746

7. Ismail SA, Saliba V, Lopez Bernal J, Ramsay ME, Ladhani SN. SARS-CoV-2 infection and transmission in educational settings: a prospective, cross-sectional analysis of infection clusters and outbreaks in England. Lancet Infect Dis. 2020;S1473-3099(20)30882-3. PMID: 33306981

8. World Health Organization (WHO). Protocol: Real-time RT-PCR assays for the detection of SARS-CoV-2 Institut Pasteur, Paris Geneva: WHO. [Accessed 20 Nov 2020]. Available from: https:// www.who.int/docs/default-source/coronaviruse/real-time-rtpcr-assays-for-the-detection-of-sars-cov-2-institut-pasteurparis.pdf?sfvrsn $=3662 \mathrm{fcb} 6$

9. Norwegian Institute of Public Health (NIPH). Håndbok for oppdaging, vurdering og håndtering av covid-19-utbrudd i kommunen. Kapittel 4: Risikovurdering. [Manual for detection, evaluation and handling of COVID-19 outbreak in the municipality. Chapter 4: Risk assessment]. Oslo: NIPH; 2020. Norwegian. Available from: https://www.fhi.no/nettpub/ overvaking-vurdering-og-handtering-av-covid-19-epidemien-ikommunen/

10. Parri N, Lenge $M$, Buonsenso D, Coronavirus Infection in Pediatric Emergency Departments (CONFIDENCE) Research Group. Children with Covid-19 in Pediatric Emergency Departments in Italy. N Engl J Med. 2020;383(2):187-90. https://doi.org/10.1056/NEJMc2007617 PMID: 32356945

11. Folkhälsomyndigheten (Public Health Agency of Sweden). Forekomst av covid-19 i olika yrkesgrupper. Bekraftade covid-19 fall i Sverige 13 mars - 27 maj 2020. [Prevalence of COVID-19 in different occupational groups. Confirmed cases of COVID-19 in Sweden 13 March - 27 May 2020]. Stockholm Folkhälsomyndigheten; 2020. Swedish. Available from: https://www.folkhalsomyndigheten.se/contentassets/7ff1d a2c3d7140809558ddae46735aa1/forekomst-covid-19-olikayrkesgrupper-skolan.pdf

12. Norwegian Institute of Public Health (NIPH). COVID-19. Ukerapport - uke 44. [COVID-19. Weekly report - week 44]. Oslo: NIPH; 4 Nov 2020. Norwegian. Available from: https:// www.fhi.no/contentassets/8a971e7boa3c4a06bdbf381ab5 2e6157/vedlegg/andre-halvar-2020/2020.11.04-ukerapportuke-44-covid-19.pdf

13. de Gier B, de Oliveira Bressane Lima P, van Gaalen R, de Boer PT, Alblas J, Ruijten M, et al. Occupation-and age-associated risk of SARS-CoV-2 test positivity, the Netherlands, June to October 2020. Euro Surveill. 2020;25(50):2001884. https:// doi.org/10.2807/1560-7917.ES.2020.25.50.2001884

14. Folkhälsomyndigheten (Public Health Agency of Sweden). Provtagning vid PCR-påvisning av SARS-CoV-2 i de övre luftvägarna. [Sampling for PCR detection of SARS-CoV-2 in the upper respiratory tract]. Stockholm: Folkhälsomyndigheten; 2020. Swedish. Available from: https://www. folkhalsomyndigheten.se/contentassets/370eo816bcoa4f1 79613 d6ef74eg03d9/provtagning-pcr-pavisning-sars-cov-2luftvagarna.pdf

15. Chong CY, Kam KQ, Li J, Maiwald M, Loo LH, Nadua KD, et al. Saliva is not a useful diagnostic specimen in children with Coronavirus Disease 2019. Clin Infect Dis. 2020; ciaa1376. PMID: 32927475

16. Han MS, Seong MW, Kim N, Shin S, Cho SI, Park H, et al. Viral RNA Load in Mildly Symptomatic and Asymptomatic Children with COVID-19, Seoul, South Korea. Emerg Infect Dis. 2020;26(10):2497-9. https://doi.org/10.3201/eid2610.202449 PMID: 32497001

17. Johansen TB, Astrup E, Jore S, Nilssen H, Dahlberg BB, Klingenberg $C$, et al. Infection prevention guidelines and considerations for paediatric risk groups when reopening primary schools during COVID-19 pandemic, Norway, April 2020. Euro Surveill. 2020;25(22):2000921. https://doi. org/10.2807/1560-7917.ES.2020.25.22.2000921 PMID: 32524956

18. The Norwegian Directorate for Education and Training. Veileder om smittevern for skoletrinn 1.-7. trinn under covid-19 utbruddet 2020. [Guidance on infection control for school grades 1-7 during the COVID-19 outbreak]. Oslo: The Norwegian Directorate for Education and Training. [Accessed 20 Nov 2020]. Norwegian. Available from: https://www. 
udir.no/kvalitet-og-kompetanse/sikkerhet-og-beredskap/ informasjon-om-koronaviruset/smittevernveileder/

skoletrinn-1-7/

19. Stein-Zamir C, Abramson N, Shoob H, Libal E, Bitan M, Cardash

T, et al. A large COVID-19 outbreak in a high school 10 days

after schools' reopening, Israel, May 2020. Euro Surveill.

2020;25(29):2001352. https://doi.org/10.2807/1560-7917.

ES.2020.25.29.2001352 PMID: 32720636

\section{License, supplementary material and copyright}

This is an open-access article distributed under the terms of the Creative Commons Attribution (CC BY 4.0) Licence. You may share and adapt the material, but must give appropriate credit to the source, provide a link to the licence and indicate if changes were made.

Any supplementary material referenced in the article can be found in the online version.

This article is copyright of the authors or their affiliated institutions, 2021. 